\title{
On Influence of Replacing Business Tax with Value-added Tax on Enterprise Finance and Taxation and Countermeasures
}

\author{
Wenyuan Chen
}

Jiangsu Vocational Institute of Commerce, Nanjing Jiangsu, 211168, China

\begin{abstract}
Key words: Replacing the business tax with a value-added tax, Enterprise finance and taxation, Influence, Countermeasures.
\end{abstract}

\begin{abstract}
Full implementation of replacing the business tax with a value-added tax not just relieves enterprise tax burden and contributes to connection of domestic and international tax system, but also generates extensive influence on enterprise pricing system and financial accounting. Financial and accounting personnel should adopt corresponding countermeasures to ensure smooth implementation of replacing the business tax with a value-added tax. If China succeeds in replacing the business tax with a value-added tax, it will provide demonstration to the world, and other countries may imitate China and expand the taxation range of value-added tax.
\end{abstract}

\section{Introduction}

On May 5, 2016, China overall implemented replacement of the business tax with a value-added tax and expanded original demonstration point range to building industry, real estate, financial industry and service industry. To make sure tax bearing of all industries decrease, China brings newly increased added-value tax of real estate into the deduction range ${ }^{[1]}$. So far, it has been four years since full implementation of replacing the business tax with a value-added tax. Enterprise tax burden has relieved greatly, and economic benefit of enterprises has improved. Economic development of small and medium-sized enterprises also has accelerated. Meanwhile, national tax revenue system has been further improved. The implementation of replacing the business tax with a value-added tax contributes to deepening the reform of financial and tax system and connecting domestic and international tax system. Indeed, replacing the business tax with a value-added tax brings positive influence on enterprise development. But, some negative effects are also generated due to restrictions of some factors. Financial and accounting personnel of enterprises should adopt corresponding countermeasures to reduce negative effects and increase positive effects so as to ensure smooth implementation of replacing the business tax with a value-added tax.

\section{Influence of replacing the business tax with a value-added tax on enterprise finance and taxation}

\section{Positive influence of full implementation of replacing the business tax with a value-added tax on enterprise finance and taxation}

Full implementation of replacing the business tax with a value-added tax conforms the thought of supply side reform and contributes to enterprises to grasp the opportunity of tax system reform, accelerate economic development mode change and strive for profit maximization. The main and direct positive influence is to avoid repeated taxation, further relieve enterprise tax burn, make enterprises have more funds for research, development, innovation and improvement of 
comprehensive competitiveness, and speed up transformation and upgrade of traditional industries. Next, this paper analyzes how to further relieve tax burden.

Firstly, the added-value tax only increases tax levy for "value-added" part. This significantly relieves enterprise tax burden.

Secondly, full implementation of replacing the business tax with a value-added tax can further reduce tax burden. For example, a real state enterprise has 80 million (excluding tax) real estate investment, and $11 \%$ tax rate will be levied according to building and real estate industry. The value-added tax of newly added real estate can be included in the reduction range. Thus, 8.8 million Yuan can be reduced, and the tax can be deducted within two years. In this way, the enterprise will have more financial strength to support enterprise transformation and development.

Thirdly, with full implementation of replacing the business tax with a value-added tax, tax reduction can be achieved for many tax-exempt items. In living service industry, the child care and education services of nurseries and kindergartens as well as service for the old in nursing institutions for the old can enjoy tax exemption. In financial industry, petty loan of peasant households, state loan for student, national debt and local government debt are tax-exempt. The policy of "making all industries reduce tax burden” is implemented, and the service industry is also supported.

Full implementation of replacing the business tax with a value-added tax brings obvious tax reduction effect for service industry, small and medium-sized enterprises and facilitates further development of small and medium-sized service enterprises. For example, value-added tax is calculated according to 3\% tax rate for small and micro enterprises. According to statistics, 641.2 billion Yuan of tax revenue will have been reduced by the end of 2015. When all enterprises complete replacement of the business tax with a value-added tax, tax reduction amount will reach RMB 900 billion according to the report of China International Capital Corporation Limited.

\section{Negative influence of full implementation of replacing the business tax with a value-added tax on enterprise finance and taxation}

In the tax system reform practice of full implementation of replacing the business tax with a value-added tax, China effectively reduces enterprise tax burden, speeds up transformation and upgrade of traditional industries, and brings many positive effects on enterprises. However, the negative effects shall not be ignored. After the business tax is replaced with a value-added tax, enterprise operation structure and management system will change. Especially, small and medium-sized enterprises will be seriously affected, and some enterprises will suffer impacts.

Firstly, they do not adapt the mode of replacing the business tax with a value-added tax. The policy of replacing the business tax with a value-added tax changes tax revenue mode, while enterprises have completely adapted previous tax revenue mode. After the change, if enterprises fail to adjust the countermeasures in time, their economic benefit will be affected for the time being.

Secondly, the profit of some enterprises will decrease. For the enterprises whose withholdings on value-added tax cannot be deducted or deductible tax is less, their profit will decrease. For instance, if a construction enterprise wants to actually reduce tax burden, withholdings on value-added tax for deductible value-added tax must account for at least $8 \%$ of total sales volume. However, many construction enterprises cannot reach $6 \%$. There are many reasons. One is that business tax belongs to the tax included in price, while value-added tax belongs to tax excluded in price. Besides, there are also the effects of labor force, material and equipment cost.

Thirdly, products trigger reduction of tax increase benefit. For instance, when an enterprise carries out sales promotion, relevant department will regard it as a marketing activity. During levying business tax, the business volume gained from sales promotion will be regarded as operation revenue. This increases business tax cost of the enterprise and brings about adverse effect on its economic benefit.

Fourthly, financial management of enterprises is influenced. During implementing replacement of the business tax with a value-added tax, financial management contents of enterprises will change to some degree, and financial management mode of enterprises is also changed. Thus, the problems 
which affect economic development occur frequently in the process of financial accounting. Thus, enterprises suffer serious economic benefit loss.

Fifthly, adverse effect is caused to financial statements. Because value-added tax belongs to tax excluded in price, the tax cannot be divided into the inventory cost. Thus, enterprises' inventory value decreases, which brings about serious influence on cost control work. Besides, debt decrease problem may easily occur to enterprises due to tax burden, which further affects enterprises' economic benefit.

Sixthly, tax bearing is aggravated, because there is no deductible voucher. For those service enterprises with high cost such as vegetable material in catering industry as well as sand and stone in building industry, enterprises' tax burden will be aggravated, because they lack deductible input tax voucher of valued-added tax. For example, corresponding special voice for value-added tax cannot be issued for labor force cost of construction enterprises, and it is not within the range of deduction, so it cannot be deducted as withholdings on value added tax. This will also increase enterprises' tax burden. Besides, special voice for value-added tax cannot be issued for enormous removal expenses of construction enterprises, and the expenses can only be included in total construction cost. This will inevitably increase tax burden.

\section{Enterprise finance and taxation management countermeasures under background of full implementation of replacing the business tax with a value-added tax}

It has been for months since full implementation of replacing the business tax with a value-added tax, and certain effect has been achieved. This can not just improve tax policy of China, but also boost core competitiveness of enterprises. Some enterprises suffer adverse effects on finance and taxation and serious economic benefit loss after replacing the business tax with a value-added tax. Relevant management personnel and accounting personnel shall pay attention to it and actively face negative effects, analyze them in an all-round, objective and systematic way and estimate enterprise tax burden data through scientific and reasonable means. They should not merely pay attention to budgeting enterprise operation fund, but also attach importance to enterprise profit and take active actions to solve problems, reduce loss, improve enterprise image and lay a good foundation for enterprise development ${ }^{[2]}$.

\section{To balance withholdings on value-added tax and value-added tax amount}

Under the background of replacing the business tax with a value-added tax, relevant management personnel should focus on the degree of balance between withholdings on value-added tax and value-added tax amount. This is mainly because in the policy of replacing the business tax with a value-added tax, withholdings on value added tax can serve as the object of deduction. Enterprises can control withholdings on value added tax and make the value-added tax amount reduce. In this way, enterprises can effectively reduce tax cost expenditure and lay a foundation for economic benefit promotion. For example, when operating revenue of an enterprise is too high, the enterprise will also increase the value-added tax to be paid. Relevant management personnel must pay attention to it, promote the limit of withholdings on value added tax through increasing procurement and deduct more input tax ${ }^{[3]}$.

\section{To make the best of the policy of replacing the business tax with a value-added tax}

When implementing replacement of the business tax with a value-added tax, the state also proposes many preferential policies beneficial to development of small and medium-sized enterprises to make them improve their development efficiency on the basis of no influence on state taxation. Thus, enterprises can make the best of these preferential policies in actual development process. For example, sudden increase in tax bearing often occurs to the enterprises in some experimental areas, so they are affected to different degrees. Relevant enterprises can submit the application to state tax department to gain the support of preferential policies. After the tax department handles such problem, 
tax cost of enterprises will decrease. Meanwhile, during applying preferential policies, enterprises can enhance core competitiveness on the basis of promoting their economic benefit ${ }^{[4]}$.

\section{To value cooperation with general taxpayers}

During proposing the policy of replacing the business tax with a value-added tax, enterprises can cooperate with general taxpayers to reduce tax cost and bring high deduction of withholdings on value added tax. It thus can be seen that enterprises should cooperate with general taxpayers to guarantee deduction of input tax from commodity procurement or labor service cooperation. If enterprises cannot cooperate with general taxpayers, they should cooperate with small enterprises to guarantee reduction of tax bearing limit through special invoice for value-added tax. In addition, during cooperation with small enterprises, enterprises must require small-scale taxpayers to offer good transportation services and guarantee scientific and rational calculation of price of value-added tax invoice so as to increase the deduction efficiency of withholdings on value added tax and lay a foundation for enterprise development ${ }^{[5]}$.

\section{To apply for general taxpayer}

In actual development process, enterprises should attach importance to apply for general taxpayer. If the taxpayers engaging in goods production or providing taxable services, and the taxpayers engaging in goods production or providing taxable services and operating goods wholesale or retailing exceed 500,000 Yuan annual sales volume, the value-added tax should be levied. If annual taxable income of the taxpayers operating goods wholesale or retailing exceeds 800,000 Yuan, and annual sales volume of the taxpayers providing taxable services exceeds 5 million Yuan, they should apply for general taxpayer qualification to relevant department. If annual sales volume of an enterprise does not exceed the above standards, but it can set financial accounts and accurately account output tax and input tax according to state provisions, it can also become a general taxpayer. Thus, when small enterprises apply for general taxpayer qualification, they should own complete financial data and perfect management mode in order to gain favorable tax policy support in the development process.

\section{To formulate thorough business strategy}

When the state carries out replacement of the business tax with a value-added tax, enterprises must formulate thorough business strategy and make corresponding adjustment according to operation conditions in order to better reduce tax cost. In the process of improving business strategy, enterprises should formulate sound operating profit goal and guarantee better improvement of financial management system. Meanwhile, enterprises should start from long-term development, control financial expenditure scientifically and rationally and make sure value-added tax is within the deduction range of input tax. Moreover, in order to better adjust the business strategy, relevant enterprise management personnel should keep improving management system, enhance management level, promote economic benefit and facilitate long-term development.

\section{To attach importance to professional quality of financial personnel}

Professional quality of financial personnel directly decides whether the enterprise can better cope with the influence of replacing the business tax with a value-added tax on the enterprise. However, financial personnel of some enterprises have low professional quality and cannot effectively improve financial work quality. Especially after the business tax is replaced with a value-added tax, financial personnel cannot adopt proper countermeasures. This brings out adverse effect on enterprise development. Therefore, enterprises must attach importance to professional quality of financial personnel. Firstly, there should be strict requirements for professional quality of financial personnel in the employee recruitment process. Financial personnel shall graduate from professional schools. In this way, financial work efficiency can improve. Secondly, when financial personnel take office, management personnel should offer tax policy knowledge training for them so that they can overall know policy reform situation and fully master accounting knowledge. Thirdly, relevant management 
personnel should pay attention to legal consciousness of financial personnel and make sure they can cope with well the influence of replacing the business tax with a value-added tax on the enterprise so as to smoothly implement financial work. Finally, it is required to strengthen the ability of financial personnel to handle affairs about value-added tax, make them develop good working habit in practice, improve tax work reform quality, make the enterprise well cope with the adverse effect of replacing the business tax with a value-added tax on the enterprise, fully utilize relevant preferential policies and lay a foundation for its development.

\section{Conclusion}

Full implementation of replacing the business tax with a value-added tax will not just influence enterprise tax structure, but also may generate extension influence on business mode, pricing system, sales promotion way, supplier selection mechanism, financial accounting, contract management and IT system etc. of enterprises. Enterprises need to overall and systematically cope with this policy. The success of China will offer reference for the world and generate worldwide influence. China has the most extensive range of tax base among more than 160 countries which implement value-added value (or similar tax). In financial industry, value-added tax of China is applicable to all financial services. In real estate industry, value-added tax of China is applicable to enterprise-to-enterprise, enterprise-to-individual, and individual-to-individual transactions. There are no such handling modes in other countries which implement value-added tax. If the policy of replacing the business tax with a value-added tax advances smoothly, other countries may follow the example of China and expand the taxable range of value-added tax.

\section{References}

[1] Xinhuanet, Full implantation of replacing the business tax with a value-added tax from May 1[DB/OL]. http://jjckb.xinhuanet.com/2016-03/05/c_135158105.htm,2016-03-05/2016-08-31.

[2] Mou Shuli, Study on influence of replacing the business tax with a value-added tax on enterprise finance and taxation and countermeasures. Times Finance (III), 2014(12):35-36.

[3] Huang Hengqing, Analysis of influence of replacing the business tax with a value-added tax on enterprise finance and taxation and countermeasures. Market Modernization, 2016 (2):156-157.

[4] Li Jinghong, Exploration of influence of replacing the business tax with a value-added tax on enterprise finance and taxation and countermeasures. Money China, 2014(8):255,260.

[5] Dai Jinfeng, Analysis of influence of replacing the business tax with a value-added tax on enterprise finance and taxation and countermeasures. Market Weekly: Theoretical Research, 2014(5):38-42.

[6] Chengdu Bendibao, Interpretation of key points of implementation rules of replacing the business tax with a value-added tax in 2016 [DB/OL]. http://cd.bendibao.com/news/2016325/83785.shtm, 2016-08-12/2016-08-31.

[7] KPMG China, Influence of replacing the business tax with a value-added tax on real estate, financial industry and service [DB/OL]. http://www.vccoo.com/v/03d1dc,2016-03-13/2016-08-31. 